\title{
Adjudicator 3
}

National Cancer Institute

\section{Source}

National Cancer Institute. Adjudicator 3. NCI Thesaurus. Code C150869.

An adjudicator performing the assessment that is given the designation of three. 